\title{
Robert Browning's Poem Porphyria's Lover: Viewed from the Perspective of a Short Story
}

\author{
S. M. Faisal Arafat \\ Lecturer (English), Programme Officer (Bangladesh National Commission for UNESCO), \\ BCS (General Education), Ministry of Education, Bangladesh \\ naadviarafat@gmail.com
}

DOI: http://doi.org/ 10.36892/ijlls.v3i1.521

$\begin{array}{ll}\text { Received: } & \text { Abstract } \\ \text { 11/01/2021 } & \text { Robert Browning quite as an exception to his contemporary Victorian poets } \\ \text { Accepted: } & \text { opted for the psychoanalysis of his characters in his poems. His obsession of } \\ \text { delving deeper into the psyche of his characters most often lent his poems with } & \text { the essence and atmosphere of a story, to be more accurate - a short story. } \\ & \text { Browning's readers still today hovers in the labyrinth created in his poetic } \\ \text { Keywords: } & \text { world. He leaves his readers in such a juncture from where the readers time } \\ \text { Robert Browning; } & \text { and again look back into the plot of his poems to find answers of the mysteries } \\ \text { Phorphyria's Lover; } ; & \text { invested by the poet. Stylistically being much ahead of the contemporary trend } \\ \text { Characteristics; } & \text { of poetry, Browning's poems could be labeled as futuristic. His artistic faculty } \\ \text { Short Story } & \text { in his poems can only be somewhat explained and understood if analyzed from } \\ & \text { the perspectives of a short story. Only then the crossroads where Browning } \\ & \text { leaves his readers in his poems can find a destination and provide a literary } \\ & \text { solution. One of the most extraordinary poems of Robert Browning is } \\ \text { 'Porphyria's Lover'. This paper is an analysis of the poem from the } & \text { perspective of the features of a short story. The plot and theme of the poem is } \\ \text { quite obscure especially the ending of the poem leaves the readers with a } \\ \text { feeling of puzzle and incompleteness. In order to explain this puzzle and } \\ \text { incompleteness this study presents an elaborate discussion of the } \\ \text { characteristics of short story. Then it discusses the storytelling ability of } \\ \text { Browning in his poems and finally based on the findings presents an analysis } \\ \text { of the poem to determine the matching characteristics of a short story in the } \\ \text { poem. The study is completely based on a qualitative analysis. }\end{array}$

\section{INTRODUCTION}

Robert Browning was born on May 7, 1812 in London. Browning was greatly inspired by his father to obtain knowledge of Latin and Greek literature. His father also encouraged him to study English literature and other European literature and history. His father had a wonderful knowledge of old French, Spanish and Italian literature. This knowledge as an inheritance passed to Browning from a library of about 6000 volumes (Hawlin, 2012). This diverse knowledge gathered at the very young age helped Browning shape up as a poet. Young Browning was greatly influenced by his immediate predecessors of English literature - the Romantics. Browning grew up with the ever-growing fame of Shelley and Keats (Chesterton, 1908). Though Browning had seen the rise of the Romantics and the ups and downs of the French Revolution in his growing years in England, his own literary technique of writing poems developed as something completely different from others. $\mathrm{He}$ was on his own and alienated. "Browning's theory of composition involves an uncompromising commitment to originality" (Woolford \& Karlin, 2014, p. 1). This sense of 
originality in Browning had different critical remarks but his sense of originality as extremely desired by Browning himself resulted into a psychological analysis of the characters in his poems. This psychological analysis needed the assistance of the art of story-telling in poetry. Browning opted for 'dramatic monologues' and excelled in. One of Browning's earliest poems Porphyria's Lover (1836) has been addressed in this study from the perspective of a short story. Browning has been discussed and analyzed from various perspectives of psychoanalysis in his poems but this study specifically focusing on finding out the elements or characteristics of a short story is believed to a shed a new light into the critical world of Robert Browning. In order to develop the analysis, this study first constructs a framework for the definition of a short story form the existing resources. Then analyses Browning's storytelling ability in his works and determines the matching characteristics of a short story generally found in Browning's writings. After that, discusses the plot and storyline of the poem Porphyria's Lover and finally evaluates the poem against the standard framework of a short story.

\section{LITERATURE REVIEW LEADING TO THE THEORITICAL FRAMEWORK}

Oxford Advanced Learner's Dictionary defines short story as "a story, usually about imaginary characters and events, that is short enough to be read from beginning to end without stopping" (Hornby, 2000, p. 1187). According to Cambridge Dictionary a short story "is an invented story that is no more than about 10000 words in length". The definition of short story included in NTC's Dictionary of Literary Terms is "a fictional narrative in prose, ranging in length from 500 words to about 15000 words, often, though certainly not always, limited to a very few characters, a single setting, and a single incident" (Morner \& Rausch, 2004 , p. 201). A general characteristic of a short story arises from the definitions as such that a short story does not entertain any wastage of words. A short story is "tight, sharp, economic, well-knit and charged" (Burroway, 1987 as cited in Taylor, 2000, p. 3). A short story can be tragic, comic, or even satiric. It can represent a work of realism, naturalism, or fantasy but chief characteristic a short story maintains is its unity. Poe called it 'the unity of impression'. However this unity also includes the unity of effect, tone, and mood (Morner \& Rausch, 2004).

Critics and researchers argue that short stories got originated from the romantic tradition having its beginning from the myths and legends (Rohrberger, 2004). The myths and legends actually gave birth to the earliest forms of narrative literature in the shape of prose fictions. These prose fictions gradually developed into numerous forms of novels, stories, and finally short stories as one of the latest literary genres. The definition of a short story included in the book A Glossary of Literary Terms holds this notion very clearly: "A short story is a brief work of prose fiction, and most of the terms for analyzing the component elements, the types, and the narrative techniques of the novel are applicable to the short story as well" (Abrams, 2005, p. 295). However, there has been a lot of debate over the issue of the relationship between novel and short story; all the debates tend to go back to the distinction, again made by Poe as one of the pioneers of short stories in English literature. Poe's distinction is of course based on the facts of length and historical ancestry (Colibaba, 2010). Another very prominent distinctive factor between the novel and the short story, according to Rohrberger (2004) is:

In the novel, readers move through time in such a way that it propels them on. Readers desire the novel to continue even through successive generations. In the short story readers move in time in such a way that it catapults them from beginning to end and back again, so strong is their desire to read what is already there (p. 7). 
This tendency of rereading as one of the most extraordinary features of a short story has famously been used in the definition of short story given by Rabindranath Tagore. His words from the poem Barsayapan (Living with Rain) has been translated into Banglapedia as following:

Simple events of life, happy or sad, some sad strings from the train of forgetfulness, not fraught with heavy descriptions, not crowded with events, no advice, no philosophy, only the feeling that the story is not yet over although there is no more to read (Short Stories, para, 3).

This definition can also lead the readers to a potential distinction between a story and a short story. The difference is in the plot. A proper story is a well-constructed plot whereas a short story is more than a plot. In a story the plot is presented such a way that it shows a situation where a conflict exists; the conflict leads to an action; the action to resolution. So, it can be said that a conflict presented and developed in a story must come to an end. There must be a solution of the conflict (Taylor, 2009). So, a reader when after finishing a story receives an impression of a conclusion, the same reader after finishing a short story is under the impression that a short story even being finished is yet to finish. That is exactly what Rabindranath Tagore implied in his definition.

So from the discussion above it can be said that a short story emerges as being characterized a brief narrative with the development of a plot in a complicated way. Here the word 'complicated' refers to the adjustment of the plot within a very limited scope as the short story is always very brief. This brevity does not allow a short story to entertain too many characters involved in the story, rather the incidents center around a single chief character. Within a certain word limit a short story is designed to the give such an impression to the readers that leaves the readers with so much thought provocation. It is something like that the effect of a short story remains as a hangover on the readers for quite a long time. However, the definition which appears to fit in, with all the possible characteristics of a short story, most appropriately reminds of the definition given by Esenwein (1961) as cited in Colibaba (2010):

A short story is a brief, imaginative narrative, unfolding a single predominating incident and a single chief character; it contains a plot, the details of which are so compressed, and the whole treatment so organized, as to produce a single impression (p. 226).

\section{METHODOLOGY}

When a set of standard characteristics of a short story has been identified from the review of literature, now the methodology of this study, in order to establish the findings, is directed and determined against three major indicators. The first one is to analyze how far the art of poetry can contain the elements of a story in it. This has been done analyzing the existing resources as documents. The second one is to discover the story telling ability of Robert Browning in his poetry. Finally, the third one is to present a parallel analysis of the poem Porohyria's Lover with the emerging characteristics of a short story from the theoretical framework of the study. Here it is very important to mention that the theoretical framework for this study just does not end with developing a set of standard characteristics of a short story rather moves further as a simultaneous process of methodology in order to complement the findings.

\subsection{ELEMENTS OF STORY IN POETRY}

This part of analysis in the study begins from the ancient literature. Aristotle in his Poetics discussed and analyzed poetry as something whole. He defined poetry as an art of imitation. Under the general heading of poetry he included epic and tragic poetry, comedy, 
and dithyrambic poetry and other forms of music. According to him the differences among these were the media by which and how they were represented. However, according to Aristotle, the form of art during his time, either in prose or in verse was yet to get any distinctive name. In spite of his making some distinctions among different form of art, it was customary to call composers as generally as poets during his time (Aristotle, 1965). These earliest forms of poetry gradually evolved into different forms of literature over the period of time. Earliest tragedies represented men as better; comedies as men as worse. Epics used to describe tales of chivalry primarily as oral forms and later on developed as written literary pieces in the form of literary epic. So, all these are indeed story-telling.

The earliest and one of the greatest epics or heroic poems in English literature is Beowulf (Long, 2007). Beowulf is a complex and digressive piece of literature with so many episodes that it is quite impossible to give a brief synopsis of the narrative. However, the outline can be drawn as Beowulf, son of Ecgtheo, sails to Denmark to fight a terrible monster called Grendel. Defeating Grendel, victorious Beowulf returns to his native land and becomes the king of Greatas. The poem concludes with the funeral of the great hero who after receiving a mortal wound while fighting a fierce dragon finally succumbs to death (Albert \& Stone, 1979). So, it can be said that the earliest piece of poem in English literature is also a story, a story delivered in verses. Among many standard definitions of poetry, one which can relate poetry most with a story is "literature in its most intense, most imaginative, and most rhythmic forms. Poetry differs from prose most basically in being written in lines of arbitrary length instead of in paragraphs" (Morner \& Rausch, 2004, p. 169). A poem that tells a story is basically known as a narrative poem. Among many types of narrative poetry, epics and ballads are two of the most prominent types. Some examples of various famous narrative poems are Geoffrey Chaucer's Canterbury Tales, Robert Frost's The Death of the Hired Man, Henry W. Longfellow's Evangeline, Mona Van Duyn's The Vision Test, Alfred Lord Tennyson's The Charge of the Light Brigade, and Amy Lowell's Patterns (Morner \& Rausch, 2004).

\subsection{BROWNING'S STORY-TELLING ABILITY}

Robert Browning faced serious criticism especially during the early years of his career. Browning's contemporary writers and critics often failed to understand his works because of certain obscurity in his writings. For more than thirty years in his career he was ridiculed and criticized fiercely but he remained working bravely and cheerfully finally making the world recognize him and follow him. Browning excelled in the form called dramatic monologue in which a single speaker speaking to a single listener or listeners revealed a dramatic situation. Browning himself called his dramatic power 'the history of a soul' (Long, 2007). "His method is to take a character at a moment of crisis and, by allowing him to talk, to reveal not only his present thoughts and feelings but his past history (Albert \& Stone, 1979). Browning himself, by using the $19^{\text {th }}$ century critical terms 'subjective' and 'objective' contrasts two different kinds of poets. The objective poet, according to him, is more concerned about "men and their actions". The objective poet is impersonal and his poems are narrative and dramatic. A subjective poet, on the other hand, expresses his personal feelings and emotions in the form of lyric (Ryals, 1983). Thus, the objectivity in Browning's poems evolving from the narrative and dramatic techniques leads to his storytelling ability.

\subsection{CHARACTERISTICS OF A SHORT STORY IN PORPHYRIA'S LOVER}

Porphyria's Lover is one of the early dramatic monologues of Robert Browning. The bottom line of the story in the poem is about a man who kills his beloved Porphyria and waits 
for God's punishment but God does not show up (Maxwell, 1993). The very setting gives a grim atmosphere of a psychological horror. The lover as the narrator or speaker of the poem appears a person with certain psychological disorder. Eggenschwiler (1970) has called this poem a psychologically complex dramatic monologue where the speaker, a struggling mind, to protect himself from an intolerable situation tries to justify the killing of his innocent beloved. The speaker seems to play a game of self-delusion and convinces himself that his act of the murder is justified. Even the very end, the concluding line of the poem speaks of his confidence of being not guilty: "And yet god has not said a word" (Poetry Foundation).

Now, going back to the development of the plot in the poem, it is found that the story in the poem begins with the description of a night where the weather is very tumultuous. The rain and wind seem to create a ghostly atmosphere. There is a certain melancholy in the air and the speaker of the poem seems to be provoked and obsessed with this overpowering mood of melancholy. To set this melancholic tone Browning very skillfully has used the imageries of 'night', 'rain', and 'wind': "The rain set early in to-night / The sullen wind was soon awake / It tore the elm-tops down for spite / And did its worst to vex the lake" (Poetry Foundation).

Amidst this extremely inclement weather, leaving behind her society, social status, and her family Porphyria arrives at the distant cabin of her lover deep in the middle of the woods. As if it were destiny for the lovers to meet; Porphyria was determined to leave behind her name and comfort, and the lover being quite sure was waiting for her arrival. Furious nature, frowning threats and iron scriptures of society nothing could come on to their way of unification. Wet in the rain, exhausted by the journey, but happy with the sight of his lover innocent Porphyria lays over her hair on the shoulders of her lover. If this is the climax of the story, then a reader is supposed to be prepared for an ending where the lovers would live happily or the reader might expect Porphyria's mighty family to come in search of her and eventually the lovers might be separated. But Browning had other ideas to convey to his readers. He introduces such an anticlimax which is beyond any wildest expectations. The lover strangles Porphyria to death by her own hair looping them for three times around her throat: “...I found / A thing to do, and all her hair / In one long yellow string I wound / Three times her little throat around / And strangled her..." (Poetry Foundation).

The psychological disorder of the lover or the speaker of the poem becomes evident when he calls his act as his victory by which he has made the purest moment of their love affair immortal. No one could snatch away his Porphyria from him now. Even he believes Porphyria had agreed and allowed the act of murder as she had still been smiling when she had been strangulated. The lover even believes his act to be divine since all through the night God did not speak a word let alone inflicting any punishment upon him.

Now, if a parallel interpretation is drawn between the plot of the poem Porphyria's Lover and the characteristics of conventional short story, it certainly appears that the plot of the poem is quite complex. It tells the story of a single night. So, the incidents also seem to happen within a very limited amount of time thus leaving the span of the story very brief. This nature of brevity is complemented by the involvement of only two characters: the anonymous lover and Porphyria. The lover is the single dominating character as generally happens in a short story. If again the characteristics of a dramatic monologue are considered, then the lover is the speaker and Porphyria remains as the only silent listener of the poem. The plot itself bears the testimony of Browning's own style of creating stories in his poem through psychoanalysis. Finally the end of the poem is so extraordinary that it leaves the readers with an endless series of questions. The reader goes back to the story time and again 
to find the answer of the end 'only to feel that the story is not over yet although there is nothing left to read.'

\section{CONCLUSION}

A man is an extremely passionate lover. He receives his beloved at his tiny house in the midst of the woods in such an inclement night where heaven and earth seem to be terrorized and toppled due to the fury of nature. There is an impression of something ominous from the very beginning of the poem Porphyria's Lover. The description of the furious nature of that very night appears quite a match with the notoriously famous storm scene in Shakespeare's King Lear. Here in the poem we see a young woman leaving behind her name, her family and everything reaches the place of her lover, they two sit face to face and suddenly the lover strangulates the beautiful woman to death. Who on earth could have thought of such an incident to occur with the usual setting and development of the poem! Browning could and Browning did. Even he moved forward to such an insane end of the poem where he put the lover waiting for divine punishment but divinity was yet to arrive. Now, imagine a reader sitting in such a situation. What an end! Could this be an end! If it could then how an ordinary reader gets the answers of his/her questions. There is no need to place an argument to justify the end of the poem. Browning always had his liberty to design his poetic mind. This study also never attempted any justification. It just presented an analysis of a possible explanation of the poem and especially the end of the poem comparing with a far newer branch of literature in the form of short story. This might satisfy a reader's questions and might ignite new ventures for researchers of Browning to explore more and more into his obscure world.

\section{REFERENCES}

Abrams, H. M. (2005). A glossary of literary terms. ( $8^{\text {th }}$ ed). Thomson Wadsworth. Albert, E., \& Stone, J. A. (1979). History of English literature. Oxford University Press. AM Chowdhury (2012). "Short stories". In Islam, Sirajul; Miah, Sajahan; Khanam, Mahfuza; Ahmed, Sabbir (eds.). Banglapedia: The National Encyclopedia of Bangladesh (Online ed.). Dhaka, Bangladesh: Banglapedia Trust, Asiatic Society of Bangladesh. ISBN 984-32-0576-6. OCLC 52727562. http://en.banglapedia.org/ index.php?title=Short_Stories

Aristotle. (1965). Poetics. Translated by T. S. Dorsch. Penguin Books.

Browning, R. (nd). Poetry Foundation. Porphyria's Lover. https://www.poetryfoundation. org/poems/46313/porphyrias-lover

Cambridge Dictionary (nd). Cambridge Dictionary. https://dictionary. cambridge.org/ dictionary/english/short-story

Chesterton, G. K. (1908). Robert browning. Grosset \& Dunlap.

Colibaba, S. (2010). The nature of the short story: Attempts at definition. Synergy, (2), 220230.

Eggenschwiler, D. (1970). Psychological Complexity in Porphyria's Lover. Victorian Poetry, 8(1), 39-48. JSTOR. www.jstor.org/stable/40001520

Hawlin, S. (2012). Robert Browning. Routledge. https://www.ebooktakeaway.com/ebta /titles/robert_browning/robert_browning_pdf.1.pdf

Hornby, A. S. (2000). Oxford advanced learner's dictionary. $\left(6^{\text {th }}\right.$ ed $)$. Oxford University Press.

Long, W. J. (2007). English Literature: Its history and significance for the life of the Englishspeaking world. Mrs. J. Lon.

Maxwell, C. (1993). Browning's Porphyria's Lover. The Explicator, 52(1), 27-30. 
Morner, k., Rausch, R. (2004). NTC's dictionary of literary terms. (First South Asian Edition/Special edition for Bangladesh). Friends Book Corner/ NTC Publishing Group.

Rohrberger, M. (2004). Origins, development, substance, and design of the short story. The art of brevity: Excursions in short fiction theory and analysis, 1-13.

Ryals, C. D. L. (1983). Becoming Browning: the poems and plays of Robert Browning, 18331846. Ohio State University Press.

Taylor, M. G. (2009). The short-short story. Maryville College. https:// www. maryvillecollege.edu/media/dsx/manager/Documents/Academics/SeniorStudy/Taylor. pdf.

Woolford, J., \& Karlin, D. (2014). Robert Browning. Routledge

\section{$\underline{A U T H O R ' S B I O}$}

S. M. Faisal Arafat had his graduation and post-graduation in English Literature and Language. He is presently working as a Programme Officer at Bangladesh National Commission for UNESCO (BNCU). He Joined Bangladesh Civil Service in 2016 as a member of the $34^{\text {th }}$ Batch. He has a teaching experience of almost 10 years as he started his career as a teacher in 2011 and worked in different private and public institutions in Bangladesh. His research interest lies in English Language Teaching and in Victorian Literature. 